\title{
Swaminathania salitolerans gen. nov., sp. nov., a salt-tolerant, nitrogen-fixing and phosphate-solubilizing bacterium from wild rice (Porteresia coarctata Tateoka)
}

\author{
P. Loganathan and Sudha Nair
}

Correspondence

Sudha Nair

sudhanair@mssrf.res.in

\author{
M. S. Swaminathan Research Foundation, 111 Cross St, Tharamani Institutional Area, Chennai, \\ Madras 600 113, India
}

\begin{abstract}
A novel species, Swaminathania salitolerans gen. nov., sp. nov., was isolated from the rhizosphere, roots and stems of salt-tolerant, mangrove-associated wild rice (Porteresia coarctata Tateoka) using nitrogen-free, semi-solid LGI medium at $\mathrm{pH} 5 \cdot 5$. Strains were Gram-negative, rod-shaped and motile with peritrichous flagella. The strains grew well in the presence of $0.35 \%$ acetic acid, $3 \% \mathrm{NaCl}$ and $1 \% \mathrm{KNO}_{3}$, and produced acid from L-arabinose, D-glucose, glycerol, ethanol, D-mannose, D-galactose and sorbitol. They oxidized ethanol and grew well on mannitol and glutamate agar. The fatty acids $18: 1 \omega 7 \mathrm{c} / \omega 9 t / \omega 12 t$ and $19: 0$ cyclo $\omega 8 \mathrm{c}$ constituted $30 \cdot 41$ and $11 \cdot 80 \%$ total fatty acids, respectively, whereas $13: 1$ AT 12-13 was found at $0.53 \%$. DNA G $+\mathrm{C}$ content was $57 \cdot 6-59 \cdot 9$ mol\% and the major quinone was Q-10. Phylogenetic analysis based on 16S rRNA gene sequences showed that these strains were related to the genera Acidomonas, Asaia, Acetobacter, Gluconacetobacter, Gluconobacter and Kozakia in the Acetobacteraceae. Isolates were able to fix nitrogen and solubilized phosphate in the presence of $\mathrm{NaCl}$. Based on overall analysis of the tests and comparison with the characteristics of members of the Acetobacteraceae, a novel genus and species is proposed for these isolates, Swaminathania salitolerans gen. nov., sp. nov. The type strain is $\mathrm{PA} 51^{\top}$ $\left(=\right.$ LMG $21291^{\top}=$ MTCC $3852^{\top}$ ).
\end{abstract}

Screening for acetic acid bacteria from wild rice sources resulted in isolation of a number of strains, which were tentatively identified as Gluconacetobacter, but closer examination and comparison with other strains in the family revealed that they belonged to a novel taxon. This paper describes the phenotypic, biochemical and genotypic characterizations of these novel strains, which were isolated from mangrove-associated wild rice in Pichavaram, Tamil Nadu, India. Based on comparative analysis with other related genera/species (Table 1), a novel species in a new genus within the family Acetobacteraceae, Swaminathania salitolerans gen. nov., sp. nov., is proposed.

Samples of mangrove-associated wild rice (Porteresia coarctata Tateoka) were collected from three different sites along coastal Tamil Nadu. Root, stem and leaf samples were washed in sterile water and surface-sterilized with sodium hypochlorite ( $4 \%$ ) for $5 \mathrm{~min}$, washed several times

The GenBank accession numbers for the 16S rRNA gene sequences of strains $\mathrm{PA5} 1^{\top}$ and PA12 are AF459454 and AF459455, respectively.

The fatty acid composition of isolates and type strains is available as supplementary material in IJSEM Online. using sterile water and macerated in a blender. The supernatants were serially diluted and aliquots of $100 \mu$ from stem, root or leaf macerates were inoculated into $30 \mathrm{ml}$ test tubes containing $10 \mathrm{ml} \mathrm{N}$-free, semi-solid LGI medium (Cavalcante \& Dobereiner, 1988) supplemented with $250 \mathrm{mM} \mathrm{NaCl}$. Vials were also inoculated with $100 \mu \mathrm{l}$ serially diluted rhizosphere soil and non-rhizosphere soil suspensions. These were incubated at $30{ }^{\circ} \mathrm{C}$ for 5 days. Acidproducing and nitrogenase-positive vials with a yellow surface pellicle were streaked onto LGI agar plates and incubated at $30^{\circ} \mathrm{C}$. Pure cultures were obtained from individual colonies. In total, 41 strains were isolated and, after biochemical characterization, two isolates (PA12 and PA5 $1^{\mathrm{T}}$ ) were selected for further study.

The genomic DNA was extracted from isolates as described by Ausubel et al. (1987). A large fragment of the 16S rRNA gene was amplified using primers fD1 [5'-AGAGTTTGATCCTGGCTCAG-3'; positions 7-26 in Escherichia coli (Brosius et al., 1981)] and rP2 (5'-ACGGCTACCTTGTTACGACTT-3'; positions 1513-1494) as described previously (Weisburg et al., 1991; Loganathan, 2002). Amplification products were separated on a $1.5 \%$ agarose gel in $1 \times \mathrm{TBE}$ buffer. Products were purified using a Sephaglas BandPrep 
Table 1. Bacterial strains used in this study

Abbreviations: LMG, Laboratorium voor Microbiologie, Universiteit Gent (RUG); NRIC, Nodai Research Institute Culture Collection, Tokyo University of Agriculture, Japan; CFN, cataloguing number of Centro de Investigacion sobre Fijacion de Nitrogeno, Mexico.

\begin{tabular}{|ll|}
\hline Strain & \multicolumn{1}{c|}{ Source of isolate } \\
\hline S. salitolerans PA12 & P. coarctata rhizosphere (this study) \\
S. salitolerans PA51 & P. coarctata root (this study) \\
Gluconacetobacter diazotrophicus LMG $7603^{\mathrm{T}}$ & LMG \\
Gluconacetobacter azotocaptans CFN-Ca54 & Coffee (obtained from J. Caballero-Mellado \\
Gluconacetobacter johannae CFN-Cf55 & Coffee (obtained from J. Caballero-Mellado \\
Gluconacetobacter sacchari LMG $19747^{\mathrm{T}}$ & LMG \\
Gluconacetobacter liquefaciens LMG $1382^{\mathrm{T}}$ & LMG \\
Asaia bogorensis NRIC $0311^{\mathrm{T}}$ & NRIC \\
Asaia siamensis NRIC $0323^{\mathrm{T}}$ & NRIC \\
Acetobacter aceti LMG $1504^{\mathrm{T}}$ & LMG \\
Acidomonas methanolica LMG $1668^{\mathrm{T}}$ & LMG \\
K. baliensis NRIC $0488^{\mathrm{T}}$ & NRIC \\
\hline
\end{tabular}

${ }^{\star}$ Centro de Investigacion sobre Fijacion de Nitrogeno, Cuernavaca, Morelos, Mexico.

kit (Amersham Pharmacia Biotech) and the fragment was cloned using a Fermentas InsT/A clone PCR Product cloning kit according to the manufacturer's instructions. Clones were sequenced using the ABI PRISM Dye Terminator Ready Reaction kit (Applied Biosystems) according to the manufacturer's instructions. For sequencing, the following primers were used: M13 forward and reverse, PC513F (5'-CCCGGCTACTTCGTGC-3'; positions 513-518), PC513R (5'-GCACGAAGTAGCCGGG-3'; positions 518-513), PC970F (5'-CGCGCAGAACCTTACCAG-3'; positions 970-987) and PC970R (5'-CTGGTAAGGTTCTGCGCG-3'; positions 987-970). The BLAST algorithm (Altschul et al., 1997) was used to search nucleotide databases for similar sequences. Gene sequences were manually aligned with each other and multiple alignments of the sequences were carried out with the program CLUSTAL_W version 1.6 (Thompson et al., 1994). Distance matrices for the aligned sequences were determined using the two-parameter method of Kimura (1980). The neighbour-joining method was used to construct a phylogenetic tree (Saitou \& Nei, 1987). The sequence data obtained were compared using 1450 bases. The robustness of individual branches was estimated by bootstrapping with 1000 replicates (Felsenstein, 1985).

A phylogenetic tree (Fig. 1) was constructed using 20 strains: including isolates PA12 and $\mathrm{PA} 51^{\mathrm{T}}$, and the type strains of Acetobacter aceti, Acidomonas methanolica, Asaia siamensis, Asaia bogorensis, Gluconacetobacter johannae, Gluconacetobacter azotocaptans, Gluconacetobacter diazotrophicus, Gluconacetobacter sacchari, Gluconacetobacter liquefaciens, Gluconacetobacter intermedius, Gluconacetobacter oboediens, Gluconacetobacter europaeus, Gluconacetobacter xylinus, Gluconobacter frateurii, Gluconobacter cerinus,
Gluconobacter oxydans, Kozakia baliensis and Rhodospirillum rubrum. Isolates PA12 and PA51 ${ }^{\mathrm{T}}$ constituted a separate branch within the lineage including species of the genus Asaia and distinct from the lineage containing species of the genera Acetobacter, Acidomonas, Gluconobacter, Gluconacetobacter and Kozakia. 16S rDNA sequences of isolates PA12 and PA51 $1^{\mathrm{T}}$ were $99.9 \%$ similar to each other. The sequence similarities of isolate $\mathrm{PA} 51^{\mathrm{T}}$ with the type strains of Gluconobacter frateurii, Acidomonas methanolica, Acetobacter aceti, Gluconacetobacter xylinus, Gluconacetobacter johannae, Gluconacetobacter sacchari, K. baliensis and Asaia siamensis were $92 \cdot 9,93 \cdot 2,93 \cdot 8,94 \cdot 1,94 \cdot 6,95 \cdot 1,96 \cdot 5$ and $98 \cdot 6 \%$, respectively.

Genomic DNA samples were analysed for their $\mathrm{G}+\mathrm{C}$ content by HPLC (Shimadzu SPE 10A, 10AD) as described by Ezaki et al. (1990) and Xu et al. (2000). DNA relatedness was assessed based on relative levels of reassociation to ${ }^{32} \mathrm{P}$-labelled total DNA, using the rediprime DNA-labelling kit (Amersham). Labelled DNA in independent experiments was from isolates and type strains. DNA-DNA reassociation was carried out for $16 \mathrm{~h}$ at $65^{\circ} \mathrm{C}$ and the nylon filters were washed once in $1 \times \mathrm{SSC}$ at room temperature for $15 \mathrm{~min}$ and once in $1 \times \mathrm{SSC}$ for $5 \mathrm{~min}$ at $65^{\circ} \mathrm{C}$. Autoradiography was performed for $2 \mathrm{~h}$, filter lanes were cut out and the radioactivity was estimated with a Beckman multi-purpose scintillation counter (LS 6500). The percentage reassociation was calculated for each strain tested in relation to the homologous control (Fuentes-Ramirez et al., 2001). Ubiquinone homologues were analysed quantitatively by HPLC with a C18 column. Standard preparations of Q-10 and Q-9 were prepared from cells of Gluconacetobacter diazotrophicus $\mathrm{LMG} 7603^{\mathrm{T}}$ and Acetobacter aceti LMG $1504^{\mathrm{T}}$, respectively (Franke et al., 1999; Lisdiyanti et al., 2002). 


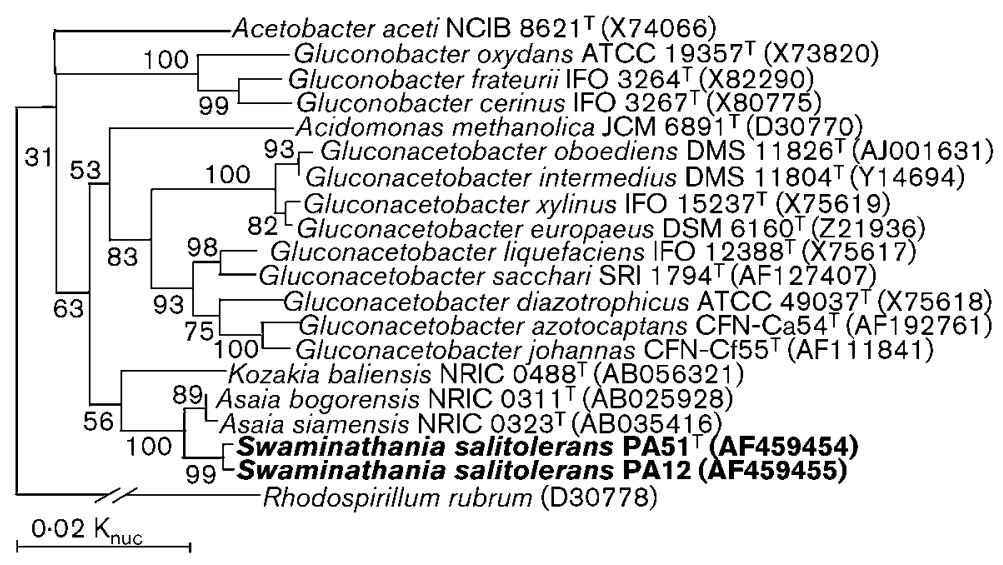

Fig. 1. Phylogenetic relationship between isolates PA12, PA51 ${ }^{\top}$ and other species of the family Acetobacteraceae determined from 16S rRNA gene sequence similarities.
Isolates PA12 and PA51 ${ }^{\mathrm{T}}$ had a $\mathrm{G}+\mathrm{C}$ content of $57 \cdot 6$ $59.9 \mathrm{~mol} \%$, which was lower than that of the type strains of Asaia bogorensis and Asaia siamensis (59-61 mol\%) and higher than that of $K$. baliensis (56-57 mol\%) (Lisdiyanti et al., 2002). The isolates had high DNA-DNA similarity values $\left(84-100 \%\right.$ between strains PA12 and PA51 ${ }^{\mathrm{T}}$ ) indicating that they belonged to the same species. Low similarity values $(12-30 \%)$ were observed with the type strains of Asaia bogorensis, Asaia siamensis and K. baliensis. The major quinone of the two isolates was Q-10.

The type of flagellation and the cell dimensions of strains PA12 and PA51 $1^{\mathrm{T}}$ were determined using cells negatively stained with $2 \%(\mathrm{v} / \mathrm{v})$ aqueous uranyl acetate at $\mathrm{pH} 3.5$ by TEM (model JEM 1200 EX11 JEO2). Five replications were used for each characterization in this study. Colony morphology was examined on LGI medium (Cavalcante \& Dobereiner, 1988). Bacterial motility was tested by growth in semi-solid medium $0.3 \% \mathrm{WL}$ nutrient agar. Oxidase and catalase tests were determined using commercially available discs (Himedia). The production of water-soluble brown pigment was determined using GYC agar medium as described by Swings et al. (1992) and overoxidation of glucose and ethanol, lactate and acetate was conducted as described by De Ley et al. (1984) and Asai et al. (1964). Tolerance to $\mathrm{NaCl}$ was also tested in SM medium (De Ley \& Swings, 1984). Pigmentation, growth on glutamate agar, ketogenic activity and acid production were tested using the methods of Asai et al. (1964).

Cellular fatty acid composition of strains PA12 and PA51 ${ }^{\mathrm{T}}$, and the type strains of Asaia bogorensis, Asaia siamensis and $K$. baliensis were estimated in cells grown on trypticase soy agar (without $\mathrm{NaCl}$ ) for $48 \mathrm{~h}$ at $30^{\circ} \mathrm{C}$. Methyl esters of cellular fatty acids were prepared and identified following the instructions of the Microbial Identification system (MIDI; Hewlett Packard).

A summary of biochemical and physiological characteristics of strains PA12 and PA51 $1^{\mathrm{T}}$ is presented in Table 2. Watersoluble brown pigment was produced on D-glucose- and $\mathrm{CaCO}_{3}$-containing agar plates. Catalase was positive and oxidase was negative. Brown pigmentation was observed on yeast extract-, D-glucose- and $\mathrm{CaCO}_{3}$-containing medium. The strains did not produce gelatinase. Acetate and lactate were oxidized to carbon dioxide and water, but the activity was weak. The isolates produced acetic acid from ethanol and grew in the presence of $0.35 \%(\mathrm{v} / \mathrm{v})$ acetic acid at $\mathrm{pH} 3.5$ and $3 \% \mathrm{NaCl}$ using $1 \% \mathrm{KNO}_{3}$ as a nitrogen source. They also grew on mannitol and glutamate agar and did not utilize methanol as a sole source of carbon on HoyerFrateur medium. Acid was produced from L-arabinose, D-glucose, D-galactose, D-mannose, glycerol, sorbitol and ethanol, but not from L-rhamnose or D-mannitol.

The predominant fatty acid found in all the acetic acid bacteria tested, including the isolates and type strains, was the straight-chain unsaturated $18: 1 \omega 7 c / \omega 9 t / \omega 12 t$, which accounted for $30.41 \%$ total fatty acid content in $\mathrm{PA} 51^{\mathrm{T}}$, compared with $43 \cdot 76 \%$ in Asaia bogorensis, $54 \cdot 29 \%$ in Asaia siamensis and $37.00 \%$ in K. baliensis. Fatty acids common to these species included $14: 0,14: 02-\mathrm{OH}, 15: 0$, $16: 0,16: 02-\mathrm{OH}, 16: 03-\mathrm{OH}, 17: 0,18: 0,19: 0$ cyclo $\omega 8 c$ and $20: 3 \omega 6,9,12 c$. However, strain PA5 $1^{\mathrm{T}}$ contained $11 \cdot 8 \%$ 19: 0cyclo $\omega 8 c$ compared with $<1 \%$ in Asaia bogorensis and Asaia siamensis, and $5.6 \%$ in K. baliensis. The fatty acid composition of isolates and type strains is available as supplementary material in IJSEM Online.

The acetylene reduction assay (ARA) was used to test the isolates grown on semi-solid LGI medium (Cavalcante \& Dobereiner, 1988) for potential nitrogen fixation. The amount of ethylene produced was measured using $10 \%$ (v/v) acetylene according to the method of Li \& MacRae (1992) using a Hewlett Packard 4890 GC equipped with a Poropack N column. Strains PA51 ${ }^{\mathrm{T}}$ and PA12 were able to reduce acetylene to ethylene. The strains were subjected to a nifD-specific PCR amplification using the primers of Ueda et al. (1995) and the expected $450 \mathrm{bp}$ amplification product was observed in both isolates. The ARA and nifD amplification results confirmed that the isolates were nitrogen fixers.

Isolates PA12 and PA51 $1^{\mathrm{T}}$ were also tested for their mineral phosphate solubilization activity. Individual strains were grown in LGI medium and $10 \mu$ grown cells were spotted 
Table 2. Characteristics differentiating S. salitolerans gen. nov., sp nov. from other members of the family Acetobacteraceae

Genera: 1, Swaminathania; 2, Asaia; 3, Kozakia; 4, Acetobacter; 5, Gluconacetobacter; 6, Gluconobacter; 7, Acidomonas. With the exception of Swaminathania, data are consolidated from our experiments and from Lisdiyanti et al. (2002) and De Ley \& Swings (1984). +, Positive; -, negative; $\mathrm{V}$, positive or negative; $\mathrm{W}$, weak.

\begin{tabular}{|c|c|c|c|c|c|c|c|}
\hline Characteristic & 1 & 2 & 3 & 4 & 5 & 6 & 7 \\
\hline Pigmentation & + & $\mathrm{V}$ & - & - & - & + & - \\
\hline Production of water-soluble brown pigments & + & - & - & - & $\mathrm{V}$ & $\mathrm{V}$ & - \\
\hline \multicolumn{8}{|l|}{ Overoxidation of: } \\
\hline Ethanol & + & - & + & + & + & + & + \\
\hline Acetate & $\mathrm{W}$ & $\mathrm{W}$ & $\mathrm{W}$ & + & + & - & + \\
\hline Lactate & $\mathrm{W}$ & $\mathrm{W}$ & $\mathrm{W}$ & + & + & - & - \\
\hline \multicolumn{8}{|l|}{ Growth on: } \\
\hline Mannitol agar & + & + & + & $\mathrm{V}$ & $\mathrm{V}$ & + & - \\
\hline Glutamate agar & + & + & - & $\mathrm{V}$ & $\mathrm{V}$ & - & - \\
\hline Methanol & - & - & - & $-{ }^{*}$ & - & - & + \\
\hline Production of acetic acid from ethanol & + & - & + & + & + & + & + \\
\hline \multicolumn{8}{|l|}{ Growth in the presence of: } \\
\hline $0 \cdot 35 \%$ acetic acid & + & - & + & + & + & + & + \\
\hline $3 \% \mathrm{NaCl}$ & + & - & - & - & - & - & - \\
\hline $1 \% \mathrm{KNO}_{3}$ & + & - & - & - & - & - & + \\
\hline Ketogenesis from glycerol & + & $\mathrm{V}$ & + & $\mathrm{V}$ & $\mathrm{V}$ & + & - \\
\hline \multicolumn{8}{|l|}{ Acid production from: } \\
\hline L-Arabinose & + & + & + & $\mathrm{V}$ & $\mathrm{V}$ & + & - \\
\hline D-Mannitol & - & $\mathrm{V}$ & - & - & $\mathrm{V}$ & + & - \\
\hline D-Glucose & + & + & + & $\mathrm{V}$ & + & + & + \\
\hline Dulcitol & $\mathrm{V}$ & + & - & - & - & + & - \\
\hline Fructose & $\mathrm{V}$ & + & - & - & + & + & - \\
\hline Glycerol & + & + & + & - & + & + & - \\
\hline Rhamnose & - & $\mathrm{V}$ & - & - & - & - & - \\
\hline D-Mannose & + & + & + & $\mathrm{V}$ & $\mathrm{V}$ & + & - \\
\hline D-Xylose & $\mathrm{V}$ & + & + & $\mathrm{V}$ & $\mathrm{V}$ & + & - \\
\hline Ethanol & + & - & + & + & + & + & + \\
\hline D-Galactose & + & + & + & + & + & + & - \\
\hline Sorbitol & + & $\mathrm{V}$ & - & + & + & + & - \\
\hline Major ubiquinone & $\mathrm{Q}-10$ & Q-10 & $\mathrm{Q}-10$ & Q-9 & Q-10 & $\mathrm{Q}-10$ & Q-10 \\
\hline $\mathrm{G}+\mathrm{C}$ content $(\mathrm{mol} \%)$ & $57 \cdot 6-59 \cdot 9$ & $59-61$ & $56-57$ & $52-60$ & $55-66$ & $52-60$ & $63-66$ \\
\hline
\end{tabular}

*Acetobacter pomorum was reported to assimilate methanol weakly (Sokollek et al., 1998).

onto Pikovskaya's medium (Pikovskaya, 1948) and the zonal clearing generated was measured. Isolates PA12 and PA5 $1^{\mathrm{T}}$ showed clearing zones on the medium, indicating that these strains were capable of solubilizing the tri-calcium phosphates contained in the medium.

The polyphasic study of acetic acid bacteria isolated from Porteresia coarctata has revealed the following characteristics. Cells of all isolates were Gram-negative, rod-shaped, approximately $0.7-0.9 \times 1.9-3.1 \mu \mathrm{m}$ and motile with peritrichous flagella. Strains were aerobic and able to fix atmospheric nitrogen micro-aerophilically. Colonies were initially yellowish, becoming dark orange later on, smooth and raised with an entire margin on LGI medium. The isolates were capable of acid formation from glucose and overoxidation of ethanol, produced water-soluble brown pigments in GYC medium, and were oxidase-negative and catalase-positive. It is well known that Gram-negative, rodshaped, aerobic bacteria that oxidize ethanol to acetic acid in neutral and acidic media are candidates for members of the family Acetobacteraceae (Swings et al., 1992). Additionally, the family Acetobacteraceae can be distinguished from other $\alpha$-Proteobacteria by two internal SphI sites and one NcoI restriction site in their $16 \mathrm{~S}$ rDNA genes (JimenezSalgado et al., 1997). Analysis of the 16S rDNA nucleotide sequence of the majority of the acetic acid bacterial strains reported in GenBank revealed that only a few strains lack the $\mathrm{NcoI}$ restriction site (nt 110) (Jimenez-Salgado et al., 1997). These restriction sites are also present in isolates PA12 and PA51 ${ }^{\mathrm{T}}$, thereby distinguishing them from the 
other $\alpha$-Proteobacteria. The BLAST search of rDNA sequences also showed that the isolates had a high similarity to members of the family Acetobacteraceae. On the basis of the phenotypic and biochemical characteristics described and restriction sites in the $16 \mathrm{~S}$ rDNA, it can be concluded that the nitrogen-fixing, salt-tolerant strains belong to the family Acetobacteraceae.

Members of the family Acetobacteraceae are recognized for their unique ability to oxidize ethanol to acetic acid in neutral and acidic media (Swings, 1992). This family consists of the genera Acetobacter, Asaia, Gluconobacter, Gluconacetobacter, Acidomonas and the recently described Kozakia (Yamada et al., 2000, Lisdiyanti et al., 2002). The isolates described in this study could be distinguished from the six genera of acetic acid bacteria at the generic level. The representative isolates showed $16 \mathrm{~S}$ rDNA similarity to Asaia (98.6\%) followed by Kozakia (96.5\%). Clustering on the basis of the neighbour-joining algorithm showed that isolates PA12 and PA51 ${ }^{\mathrm{T}}$ formed a sublineage with type genus Asaia at a similarity level of $98 \cdot 6 \%$. However, based on biochemical characteristics, these isolates differed from the type strains of the genus Asaia in production of acetic acid from ethanol, growth in the presence of $0.35 \%$ acetic acid at $\mathrm{pH} 3 \cdot 5$, acid production from ethanol and growth in the presence of $3 \% \mathrm{NaCl}$. The fatty acid 19:0cyclo $\omega 8 \mathrm{c}$ comprised $11.80 \%$ total fatty acids in isolate PA51 ${ }^{\mathrm{T}}$, compared to $0 \cdot 62-0.74 \%$ in the genus Asaia. Furthermore, the fatty acids $10: 0,10: 03-\mathrm{OH}, 12: 0,17: 1 \omega 6 c, 19: 0$ 10-methyl, 20:0, $20: 3 \omega 6,9,12 c, 15,20: 4 \omega 6,9,12,15 c$ and summed feature $4(16: 1 \omega 7 c / 15$ iso $2-\mathrm{OH})$ were not found in $\mathrm{PA} 51^{\mathrm{T}}$, whereas they were present in Asaia bogorensis, and 13:1 AT 12-13 was present in PA51 ${ }^{\mathrm{T}}$, but not in Asaia bogorensis. All these data indicate that the isolates can be distinguished from members of the genus Asaia.

The isolates could be differentiated from the genus Acetobacter on the basis of the quinone system, as the genus Acetobacter has Q-9 and the isolates and the rest of the genus have Q-10 (Yamada et al., 1997). Although the isolates oxidized acetate and lactate to carbon dioxide and water like Gluconacetobacter and Acetobacter, they differed phylogenetically from these genera and from the genus Gluconobacter, and were most closely related to the genus Asaia. The isolates also differed from the genus Acidomonas, since they did not utilize methanol as a sole source of carbon.

The isolates were able to grow well in the presence of $1 \%$ $\mathrm{KNO}_{3}$. These data indicate that the isolates may be distinguished biochemically from the genera Asaia, Acetobacter, Gluconobacter, Gluconacetobacter and Kozakia. Interestingly, the isolates were able to grow well in the presence of $3 \% \mathrm{NaCl}$ in $\mathrm{SM}$ medium, which differentiates them from the other genera. Based on the above description, it is proposed that the isolates belong to a new genus and novel species for which the name Swaminathania salitolerans gen. nov., sp. nov. is proposed.

\section{Description of Swaminathania gen. nov.}

Swaminathania (swa.mi.na.tha'ni.a. N.L. fem. n. Swaminathania after Swaminathan, Indian biologist, the father of the Green Revolution in India).

Gram-negative, straight rods with round ends, approximately $0.7-0.9 \times 1 \cdot 9-3.1 \mu \mathrm{m}$, possesses peritrichous flagella, oxidase-negative and catalase-positive. Capable of oxidizing ethanol to acetic acid in neutral and acid conditions, glucose to acetic acid, and oxidized acetate and lactate to $\mathrm{CO}_{2}$ and water. Able to produce water-soluble brown pigments on GYC agar medium. Does not hydrolyse gelatin and starch. Grows well in the presence of $0.35 \%$ acetic acid, $3 \% \mathrm{NaCl}$ and $1 \% \mathrm{KNO}_{3}$. Produces acid from L-arabinose, D-glucose, glycerol, ethanol, D-mannose,

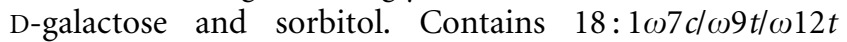
$(30 \cdot 41 \%), 13: 1$ AT $12-13(0 \cdot 53 \%)$ and $19: 0$ cyclo $\omega 8 c$ $(11 \cdot 84 \%)$. Able to fix nitrogen and solubilize phosphate. DNA G + C content is $57 \cdot 6-59 \cdot 9 \mathrm{~mol} \%$ and the major quinone is Q-10. The type species is Swaminathania salitolerans.

\section{Description of Swaminathania salitolerans sp. nov.}

Swaminathania salitolerans (sa.li.to'le.rans. L. n. sal salt; L. part. adj. tolerans tolerating; N.L. part. adj. salitolerans salt tolerating).

Characteristics are the same as those described for the genus. The type strain is PA51 $1^{\mathrm{T}}\left(=\mathrm{LMG} 21291^{\mathrm{T}}=\right.$ MTCC $3852^{\mathrm{T}}$ ), isolated from mangrove-associated wild rice in Pichavaram, Tamil Nadu, India.

\section{Acknowledgements}

This work was carried out with financial support from the Department of Biotechnology, Government of India. The authors would like to acknowledge the help extended by various people as follows: Professor H. G. Trüper for his suggestion on latin nomenclature for the novel isolate; Professor Yamada for his valuable comments in the analysis; Professor H. Kawasaki for help with phylogeny; Dr J. Caballero-Mallado, Cuernavaca, Morelos, Mexico for providing the Gluconacetobacter johannae and Gluconacetobacter azotocaptans type strains for the study; Dr Muthukumarasamy, Main Biocontrol Lab, Chingleput for the HPLC work; and Dr Rajaram, Central Leather Research Institute, Chennai, for his support in the transmission electron microscopy studies. Last but not least, Professor M. S. Swaminathan, who has been the moving spirit behind this work and in whose honour the genus has been proposed.

\section{References}

Altschul, S. F., Madden, T. L., Schaffer, A. A., Zhang, J., Zhang, Z., Miller, W. \& Lipman, D. J. (1997). Gapped BLAST and PSI-BLAST: a new generation of protein database search programs. Nucleic Acids Res 25, 3389-3402.

Asai, T., lizuka, H. \& Komagata, K. (1964). The flagellation and taxonomy of genera Gluconobacter and Acetobacter with reference to the existence of intermediate strains. J Gen Appl Microbiol 10, 95-126. 
Ausubel, F. M., Brent, R., Kingston, R. E., Moore, D. D., Seidman, J. G., Smith, J. A. \& Struhl, K. (1987). Current Protocols in Molecular Biology. New York: Wiley.

Brosius, J., Dull, T. J., Sleeter, D. D. \& Noller, H. F. (1981). Gene organization and primary structure of a ribosomal RNA operon from Escherichia coli. J Mol Biol 148, 107-127.

Cavalcante, V. A. \& Dobereiner, J. (1988). A new acid-tolerant nitrogen fixing bacterium associated with sugar cane. Plant Soil 108, 23-31.

De Ley, J. \& Swings, J. (1984). Genus II Gluconobacter asai 1935, $698^{\mathrm{AL}}$. In Bergey's Manual of Systematic Bacteriology, vol. 1, pp. 275-277. Edited by N. R. Krieg \& J. G. Holt. Baltimore: Williams \& Wilkins.

De Ley, J., Swings, J. \& Gassele, F. (1984). Genus I Acetobacter Beijerinck 1898, 215 ${ }^{\mathrm{AL}}$. In Bergey's Manual of Systematic Bacteriology, vol. 1, pp. 268-274. Edited by N. R. Krieg \& J. G. Holt. Baltimore: Williams \& Wilkins.

Ezaki, T., Saidi, S. M., Liu, S. L., Hashimoto, Y., Yamamoto, H. \& Yabuuchi, E. (1990). Rapid procedure to determine the DNA base composition from small amounts of Gram-positive bacteria. FEMS Microbiol Lett 55, 127-130.

Felsenstein, J. (1985). Confidence limits on phylogenies: an approach using the bootstrap. Evolution 39, 783-791.

Franke, I. H., Fegan, M., Hayward, C., Leonard, G., Stackebrandt, E. \& Sly, L. I. (1999). Description of Gluconacetobacter sacchari sp. nov., a new species of acetic acid bacterium isolated from the leaf sheath of sugar cane and from the pink sugar-cane mealy bug. Int J Syst Bacteriol 49, 1681-1693.

Fuentes-Ramirez, L. E., Bustillos-Cristales, R., Tapia-Hernandez, A., Jimenez-Salgado, T., Wang, E. T., Martinez-Romero, E. \& Caballero-Mellado, J. (2001). Novel nitrogen-fixing acetic acid bacteria, Gluconacetobacter johannae sp. nov. and Gluconacetobacter azotocaptans sp. nov., associated with coffee plants. Int J Syst Evol Microbiol 51, 1305-1314.

Jimenez-Salgado, T., Fuentes-Ramirez, L. E., Tapia-Hernandez, A., Mascarua-Esparza, M. A., Martinez-Romero, E. \& CaballeroMellado, J. (1997). Coffea arabica L., a new host plant for Acetobacter diazotrophicus, and isolation of other nitrogen-fixing acetobacteria. Appl Environ Microbiol 63, 3676-3683.

Kimura, M. (1980). A simple method for estimating evolutionary rates of base substitutions through comparative studies of nucleotide sequences. J Mol Evol 16, 111-120.

Li, R.-P. \& MacRae, I. C. (1992). Specific identification and enumeration of Acetobacter diazotrophicus in sugarcane. Soil Biol Biochem 24, 413-419.

Lisdiyanti, P., Kawasaki, H., Widyastuti, Y., Saono, S., Seki, T., Yamada, Y., Uchimura, T. \& Komagata, K. (2002). Kozakia baliensis gen. nov., sp. nov., a novel acetic acid bacterium in the $\alpha$ Proteobacteria. Int J Syst Evol Microbiol 52, 813-818.

Loganathan, P. (2002). Isolation and characterization of novel salt tolerant nitrogen fixing and phosphate solubilizing bacteria from wild rice - Porteresia coarctata. $\mathrm{PhD}$ thesis, Madras University, Chennai, India.

Pikovskaya, R. I. (1948). Mobilization of phosphorus in soil in connection with the vital activity of some of the microbial species. Mikrobiologiya 17, 362-370.

Saitou, N. \& Nei, M. (1987). The neighbor-joining method: a new method for reconstructing phylogenetic trees. Mol Biol Evol 4, 406-425.

Sokollek, S. J., Hertel, C. \& Hammes, W. P. (1998). Description of Acetobacter oboediens sp. nov. and Acetobacter pomorum sp. nov., two new species isolated from industrial vinegar fermentations. Int J Syst Bacteriol 48, 935-940.

Swings, J. (1992). The genera Acetobacter and Gluconobacter. In The Prokaryotes, 2nd edn, pp. 2268-2286. Edited by A. Balows, H. G. Trüper, M. Dworkin, W. Harder \& K.-H. Schleifer. New York: Springer

Swings, J., Gillis, M. \& Kersters, K. (1992). Phenotypic identification of acetic acid bacteria. In Identification Methods in Applied and Environmental Microbiology, pp. 103-110. Edited by R. G. Board, D. Jones \& F. A. Skinner. Oxford: Blackwell Scientific.

Thompson, J. D., Higgins, D. G. \& Gibson, T. J. (1994). CLUSTAL_W: improving the sensitivity of progressive multiple sequence alignment through sequence weighting, position-specific gap penalties and weight matrix choice. Nucleic Acids Res 22, 4673-4680.

Ueda, T., Suga, Y., Yahiro, N. \& Matsuguchi, T. (1995). Genetic diversity of $\mathrm{N}_{2}$-fixing bacteria associated with rice roots by molecular evolutionary analysis of a nifD library. Can J Microbiol 41, 235-240.

Weisburg, W. G., Barns, S. M., Pelletier, D. A. \& Lane, D. J. (1991). $16 \mathrm{~S}$ ribosomal DNA amplification for phylogenetic study. J Bacteriol 173, 697-703.

Xu, H.-X., Kawamura, Y., Li, N., Zhao, L., Li, T.-M., Li, Z.-Y., Shu, S. \& Ezaki, T. (2000). A rapid method for determining the $G+C$ content of bacterial chromosomes by monitoring fluorescence intensity during DNA denaturation in a capillary tube. Int J Syst Evol Microbiol 50, 1463-1469.

Yamada, Y., Hoshino, K. \& Ishikawa, T. (1997). The phylogeny of acetic acid bacteria based on the partial sequences of $16 \mathrm{~S}$ ribosomal RNA: the elevation of the subgenus Gluconoacetobacter to the generic level. Biosci Biotechnol Biochem 61, 1244-1251.

Yamada, Y., Katsura, K., Kawasaki, K., Widyastuti, Y., Saono, S. Seki, T., Uchimura, T. \& Komagata, K. (2000). Asaia bogorensis gen. nov., sp. nov., an unusual acetic acid bacterium in the $\alpha$-Proteobacteria. Int J Syst Evol Microbiol 50, 823-829. 